\title{
EPITHELIOID ANGIOSARCOMA METASTASES TO THE BONE MARROW MANIFESTING AS ERYTHROBLASTIC ANEMIA AND LEUKOCYTOSIS: A CASE REPORT AND REVIEW OF THE LITERATURE
}

\author{
Piotr CZapiewski ${ }^{1}$, Krzysztof WaŻnY ${ }^{1}$, Ewa Lewicka-NowaK ${ }^{2}$, Wojciech Biernat ${ }^{1}$ \\ ${ }^{1}$ Department of Pathology, Medical University of Gdansk, Gdansk, Poland \\ 22nd Department of Cardiology and Electrotherapy, Medical University of Gdansk, Debinki Gdansk, Poland
}

\begin{abstract}
Bone marrow is an exceptionally uncommon site of metastatic dissemination in angiosarcoma (AS) as only single case reports have been published so far. We report a case of a 72-year-old male with epithelioid angiosarcoma of the liver who subsequently developed erythroblastic anemia. The trephine bone marrow biopsy revealed total replacement of the normal hematopoiesis by diffuse infiltrate of AS. This rare complication of the clinical course of this tumor should be taken into account in the pathological diagnosis of patients with AS presenting with hematological abnormalities.
\end{abstract}

Key words: bone marrow biopsy, metastasis, angiosarcoma.

\section{Introduction}

Angiosarcoma (AS) is a rare tumor with vascular differentiation, which accounts for less than $1 \%$ of all soft tissue sarcomas [1]. Most of them arise in the skin and soft tissues, but visceral primary AS may also occur. The liver is the most common site in such an instance accounting for $8 \%$ of all ASs [1].

Epithelioid angiosarcoma (EAS) is a morphological variant of AS. It occurs in approximately $20 \%$ of all ASs. Epithelioid morphology distinguishes this variant and vascular channel formation typical of AS may be scarce or even entirely absent [2]. The correct morphological diagnosis of EAS may be difficult as the cytokeratin expression may occur in about $50 \%$ of these tumors [3]. However, a strong expression of vascular markers, such as CD31, CD34 and factor VIII is helpful in rendering the correct histopathological diagnosis.

We report a case of a 72-year-old male with the hepatic EAS metastasizing to the bone marrow, which due to its morphology could have been mistaken for an epithelial neoplasm. To the best of our knowledge, it is the ninth case of angiosarcoma metastasizing to the bone marrow reported in the literature, but the first one with the primary focus in the liver and the second one showing the epithelioid morphology.

\section{Case report}

A 72-year-old man was admitted to the Cardiology and Electrotherapy Clinic, presenting with impaired physical efficiency, chest pain, fever, night sweats, weight loss, and lower and upper back pain. The patient underwent gastrectomy 30 years earlier but no information concerning its cause was available. The blood count was: RBC $3.7 \times 10^{12} / 1$, HGB $11.7 \mathrm{~g} / \mathrm{dl}$, HCT $34 \%$, MCV $91 \mathrm{fl}, \mathrm{MCH} 31 \mathrm{pg}, \mathrm{PLT} 341 \times 10^{9} / \mathrm{l}$, WBC $15.53 \times 10^{9} / 1$. The clinical diagnosis of infective endocarditis was rendered but due to the weight loss of $15 \mathrm{~kg}$, a neoplastic process was also suspected. Computer tomography imaging of the abdomen revealed a hypodense lesion located in the fourth quadrant of the liver that was $3 \mathrm{~cm}$ in diameter. Other findings in the CT were unremarkable. 
As the patient showed signs of increasing anemia and sustained leukocytosis, a trephine bone marrow biopsy was also performed.

The patient gradually deteriorated and died 3 weeks after the diagnosis of bone marrow involvement. The autopsy was not performed.

\section{Histopathology}

The core needle biopsy of the liver was performed and obtained tissue was formalin-fixed and paraffinembedded. The slides from paraffin blocks were used for HE, CK20, CK7, CK AE1/AE3, CEA, EMA, AFP, CD 45, chromogranin, CD34, and CD31(DAKO) staining.

In the liver core needle biopsy there was an infiltration of focally necrotic, poorly differentiated epithelioid neoplasm with a high mitotic index, with a ten-

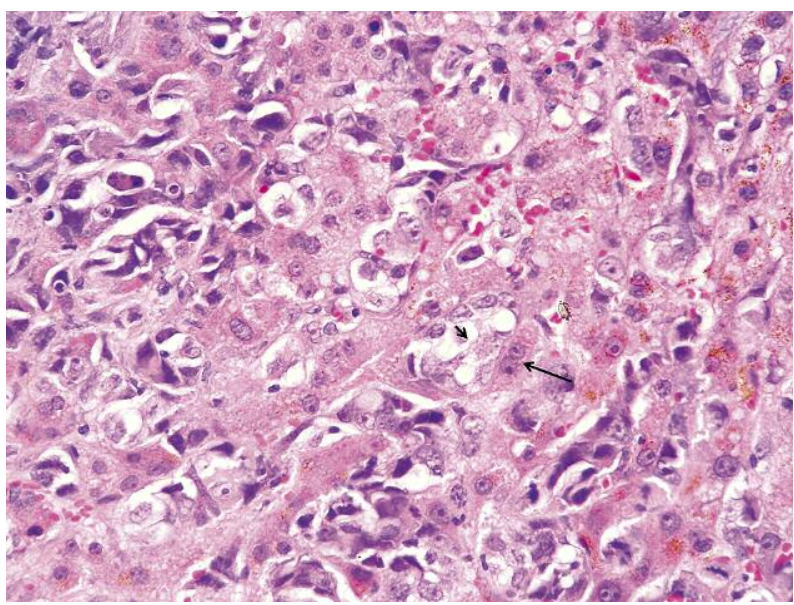

Fig. 1A. The liver. An infiltration of poorly differentiated neoplastic cells with epithelioid morphology (short arrow), with a tendency to penetrate along sinusoids between preserved hepatocytes (long arrow). Magnification $400 \times$

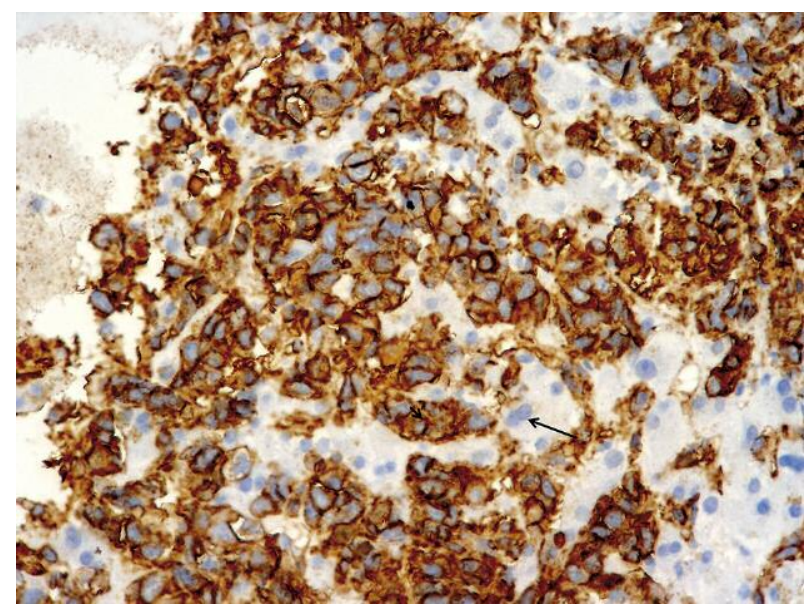

Fig. 1C. The liver. Clusters of neoplastic cells show strong immunoreactivity with the CD34 antibody, while preserved hepatocytes are CD34 negative (long arrow). Magnification $400 \times$ dency to penetrate along sinusoids between preserved hepatocytes (Fig. 1A). Despite the epithelioid morphology of the neoplastic cells, they showed negative reaction with all epithelial markers (CK20, CK7, EMA, CEA) except for weak, focal reaction with an antibody against CK AE1/AE3 (Fig. 1B). Neoplastic cells were also AFP and chromogranin negative. Lymphoid marker CD 45 was also negative. The tumor cells were strongly positive for CD34 (Fig. 1C) and CD31 (Fig. 1D). Other stainings were not performed due to the small amount of the tissue. After comparing the morphological and immunohistochemical features of this neoplasm, the diagnosis of primary epithelioid angiosarcoma of the liver was established.

The tissue from the bone marrow trephine biopsy was formalin-fixed, decalcified and paraffin-embedded.

The slides from the trephine biopsy paraffin block were used for HE, CKAE1/AE3, CK7, CK20 and

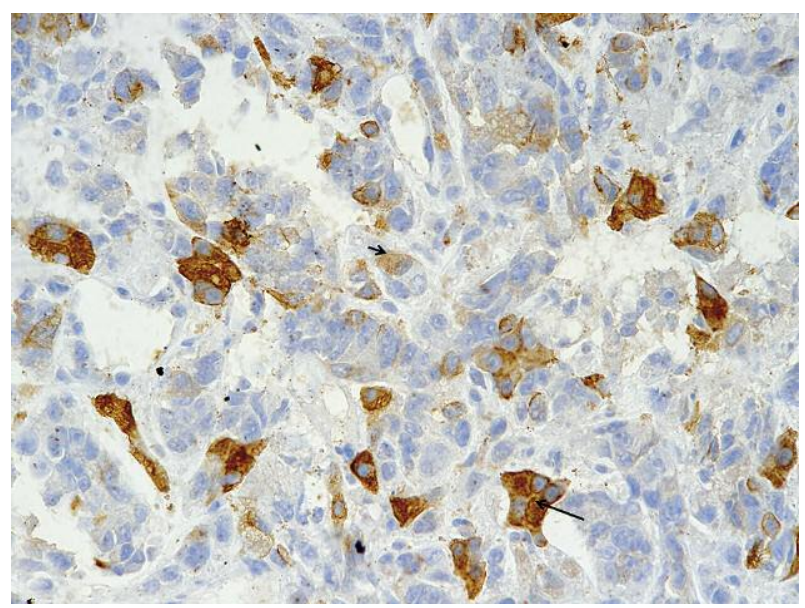

Fig. 1B. The liver. Strongly CKAE1/AE3 positive hepatocytes( long arrow) and weak and focal reaction in the neoplastic infiltrate(short arrow). Magnification $400 \times$

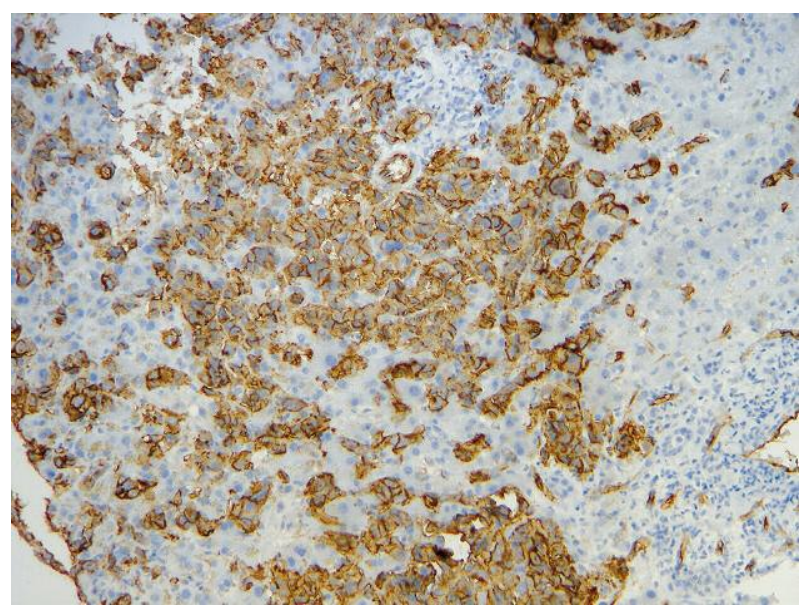

Fig. 1D. The liver. Neoplastic cells are strongly CD31 positive. Magnification $100 \times$ 

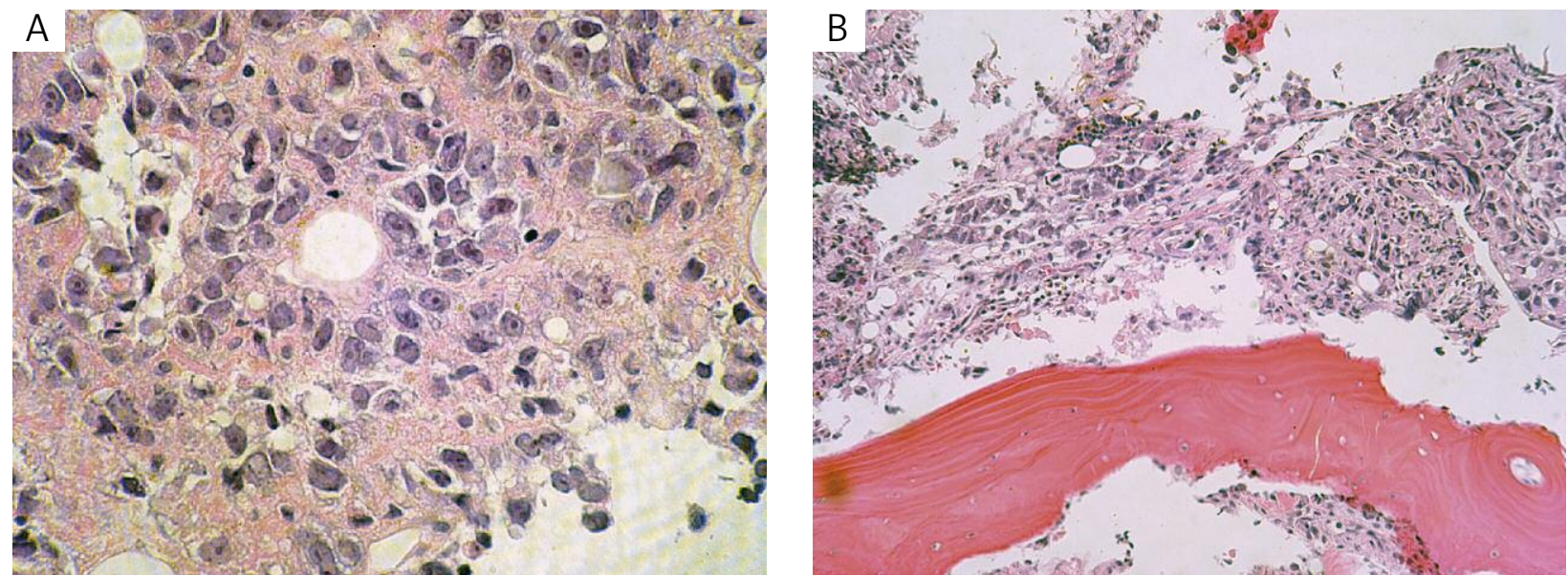

Fig. 2A, 2B. Bone marrow. Total replacement of the normal bone marrow by diffuse infiltrate of polymorphous cells with an epithelioid appearance. Magnification $400 \times(A)$ and $200 \times(B)$

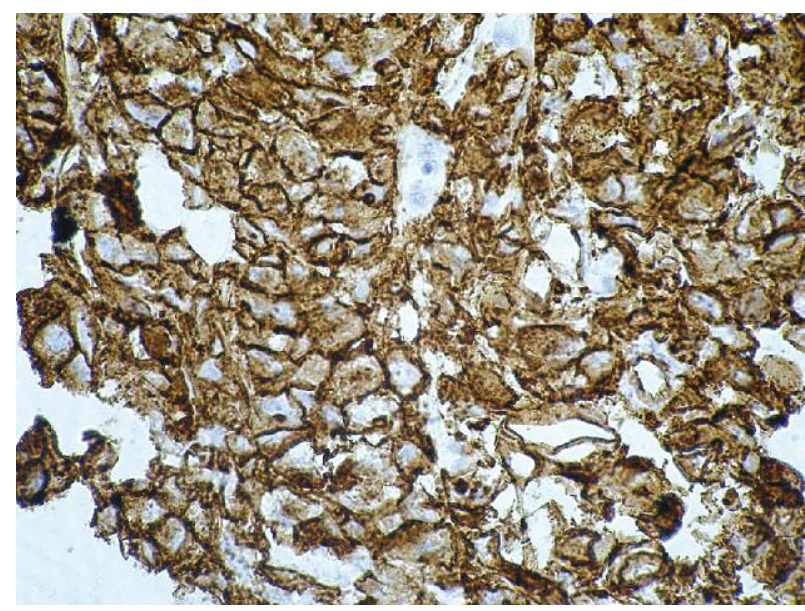

Fig. 2C. Bone marrow. Strong immunoreactivity of the neoplastic cells with the CD34 antibody. Magnification $400 \times$

\section{CD34 staining.}

Histopathological analysis of the bone marrow trephine biopsy revealed total replacement of the normal bone marrow by diffuse infiltrate of polymorphous cells with an epithelioid appearance (Fig. 2A, 2B). As the clinical history of the patient was not clear, due to lack of information concerning the cause of gastrectomy, the metastatic carcinoma was also taken into account. Immunohistochemical analysis confirmed the diagnosis of epithelioid angiosarcoma due to strong immunoreactivity with the CD34 antibody (Fig. 2C) and focal cytokeratin AE1/AE3 (Fig. 2D) and cytokeratin 7 positivity.

\section{Discussion}

Angiosarcoma is a malignant vascular tumor that shows variable clinical aggressiveness depending on the site of the development of the primary tumor. The lesions originating in the liver seem to present

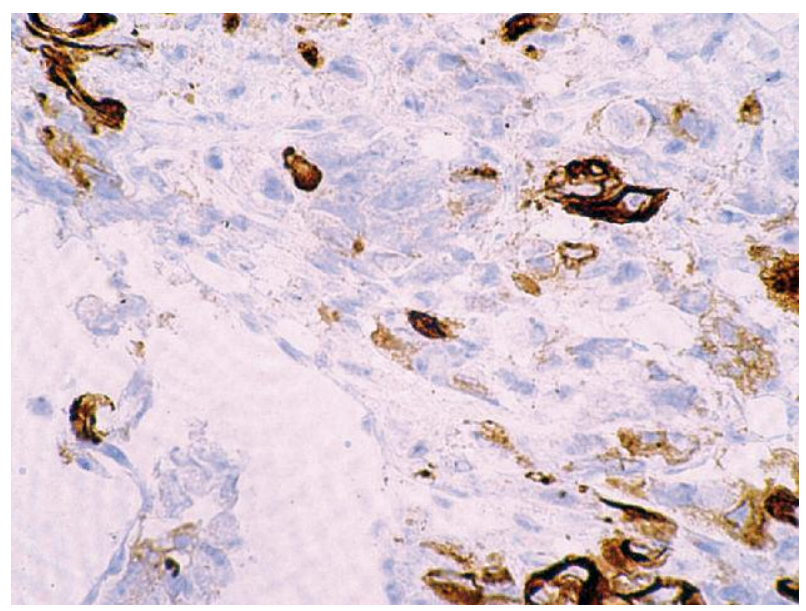

Fig. 2D. Bone marrow. The neoplastic cells were focally cytokeratin AE1/AE3 positive. Magnification $400 \times$

the worst prognosis, while cutaneous ASs are tumors with a better clinical outcome [4]. Malignant behavior of non-cutaneous ASs is also obvious from our review of the literature. All the reported cases of bone marrow involvement by AS occurred in cases with the primary tumor in the extracutaneous locations (Table I) [5-12]. These unusual metastases occurred in four cases of splenic AS, two deriving from the bone, and one case each from the sinonasal region, thyroid and the liver [5-12]. Interestingly, although splenic AS makes only $4 \%$ of ASs [1], they were responsible for $44 \%$ of bone marrow-metastasizing cases $[5,6,8,9]$. This may indicate the special predilection of splenic AS for bone marrow involvement.

In general, the bone marrow dissemination occurred at the beginning of the disease, except for one patient who suffered from bone marrow metastases 3 years after the initial diagnosis [9].

The epithelioid variant of AS accounts for approximately $20 \%$ of cases $[2,5]$ and is characterized 
Table I. Angiosarcomas metastasizing to the bone marrow described in the English-language literature

\begin{tabular}{|c|c|c|c|c|c|c|c|}
\hline $\begin{array}{l}\text { AGE } \\
\text { AT THE } \\
\text { DIAGNOSIS }\end{array}$ & GENDER & $\begin{array}{l}\text { PRIMARY } \\
\text { LOCATION }\end{array}$ & $\begin{array}{l}\text { SIGNS OF BONE } \\
\text { MARROW } \\
\text { INVOLVEMENT }\end{array}$ & $\begin{array}{l}\text { TIME TO BONE } \\
\text { MARROW } \\
\text { INVOLVEMENT }\end{array}$ & $\begin{array}{c}\text { OTHER } \\
\text { METASTASES }\end{array}$ & Outcome & REF. \\
\hline 27 & M & spleen & pancytopenia & not mentioned & not mentioned & $\begin{array}{l}\text { died, } \\
7 \text { months }\end{array}$ & {$[5]$} \\
\hline 47 & $\mathrm{~F}$ & spleen & $\begin{array}{c}\text { anemia, macro-, } \\
\text { micro- and } \\
\text { ovalocytosis }\end{array}$ & $\begin{array}{c}\text { primarily } \\
\text { diagnosed } \\
\text { on BM biopsy }\end{array}$ & $\begin{array}{l}\text { liver, bone, } \\
\text { breast, } \\
\text { soft tissue }\end{array}$ & $\begin{array}{l}\text { died, } \\
9 \text { months }\end{array}$ & [6] \\
\hline 34 & $\mathrm{~F}$ & $\begin{array}{l}\text { sinonasal } \\
\text { region }\end{array}$ & $\begin{array}{c}\text { severe anemia } \\
\text { and erythroblastosis }\end{array}$ & $\begin{array}{c}\text { primarily } \\
\text { diagnosed } \\
\text { on BM biopsy }\end{array}$ & $\begin{array}{c}\text { not } \\
\text { mentioned }\end{array}$ & $\begin{array}{c}\text { died, } \\
2 \text { weeks }\end{array}$ & [7] \\
\hline 48 & $\mathrm{M}$ & spleen & $\begin{array}{c}\text { anemia, } \\
\text { lymphocytosis, } \\
\text { thrombocytopenia }\end{array}$ & few days & $\begin{array}{c}\text { liver, } \\
\text { peripancreatic } \\
\text { lymph nodes }\end{array}$ & $\begin{array}{c}\text { died, } \\
\text { few days }\end{array}$ & [8] \\
\hline 36 & $\mathrm{M}$ & spleen & $\begin{array}{c}\text { leukoerythroblastic } \\
\text { anemia }\end{array}$ & 3 years & $\begin{array}{l}\text { retroperitoneal } \\
\text { lymph nodes, } \\
\text { liver, } \\
\text { lumbar spine, } \\
\text { kidney }\end{array}$ & $\begin{array}{c}\text { died, } \\
4 \text { years, } \\
1 \text { year } \\
\text { after bone } \\
\text { marrow } \\
\text { involvement }\end{array}$ & [9] \\
\hline 54 & $\mathrm{M}$ & $\begin{array}{c}\text { bone } \\
\text { (thoracic spine) }\end{array}$ & $\begin{array}{l}\text { severe anemia } \\
\text { and } \\
\text { thrombocytopenia }\end{array}$ & $\begin{array}{c}\text { primarily } \\
\text { diagnosed } \\
\text { on BM biopsy }\end{array}$ & $\begin{array}{c}\text { smaller } \\
\text { metastatic } \\
\text { foci in the } \\
\text { spine and skull }\end{array}$ & $\begin{array}{c}\text { died, } \\
6 \text { weeks }\end{array}$ & [10] \\
\hline 56 & $\mathrm{~F}$ & thyroid & $\begin{array}{c}\text { severe } \\
\text { erythroblastic anemia }\end{array}$ & 10 weeks & lungs & $\begin{array}{c}\text { died, } \\
12 \text { weeks }\end{array}$ & {$[11]$} \\
\hline 77 & $\mathrm{~F}$ & bone (iliac) & no & $\begin{array}{c}\text { primarily } \\
\text { diagnosed } \\
\text { on BM biopsy }\end{array}$ & $\begin{array}{c}\text { not } \\
\text { mentioned }\end{array}$ & $\begin{array}{c}\text { not } \\
\text { mentioned }\end{array}$ & [12] \\
\hline 72 & $\mathrm{M}$ & liver & anemia, leukocytosis & 2 weeks & lungs & $\begin{array}{c}\text { died, } \\
3 \text { weeks }\end{array}$ & apiewski \\
\hline
\end{tabular}

by epithelioid morphology with scarce or even entirely absent vascular channel formation [2]. Additionally, EASs express cytokeratins in around $50 \%$ of cases [3] and it makes differentiation from carcinomas more challenging. A strong expression of vascular markers, such as CD31, CD34 and factor VIII may be helpful in reaching a correct histopathological diagnosis [13].

Although CD34 shows relatively low immunoreactivity in solid, poorly differentiated areas of ASs [13], in our case, the neoplastic cells, although showing strikingly solid morphology, strongly expressed CD34 both in the primary location as well as in the bone marrow metastasis.

The fine needle aspiration biopsy (FNAB) is not the preferential way of diagnosis in patients with AS. Correct diagnosis was established in 37,5\% of these tumors[14]. However, EAS seems to be more easy to diagnose by FNAB, because the smears are usually cellrich $(100 \%$ vs. $50 \%$ in the classical variant), they are constantly composed of round to oval and polygonal epithelial-like cells with frequent clustering in contrast to morphological diversity presented by the classical variant of AS. In addition, erythrophagocytosis is much more frequent in EAS (80\% vs. 33\%). Therefore, concurrent epithelioid morphology and erythrophagocytosis is strongly suggestive of EAS [14]. The diagnosis of the epithelioid variant of AS can be of clinical significance since the diagnosis of cutaneous EAS may confer worse prognosis, as was shown in a recent report by Deyrup et al. [2]. However, it is unclear whether this morphological variant influences the clinical course in AS developing in other clinical settings and locations.

The prognosis in patients with AS involving the bone marrow is dismal with the survival time ranging between several days and one year [5-12].

Although distant metastases in AS correlate with significantly shorter survival comparing with non-metastasizing ones, it is possible to achieve long-term survival in $20 \%$ of disseminated ASs [4].

The differential diagnosis of epithelioid angiosarcoma (EAS) includes carcinoma, malignant peripheral nerve sheath tumor (MPNST), epithelioid hemangioen- 
dothelioma (EHE), malignant melanoma, anaplastic large cell lymphoma and epithelioid sarcoma.

Carcinomas consistently express broad spectrum cytokeratins (CKAE1/AE3) and respective subtypes of cytokeratins depending on the type of the epithelium they derive from. The vascular markers are consistently negative.

MPNST can show striking histological similarity to the EAS and immunophenotyping is crucial in the differential diagnosis. Contrary to the angiosarcoma, MPNST shows a rare expression of CD34 and lack of other vascular markers (eg. CD31, D2-40) and expression of S-100 protein [15].

Despite a similar immunohistochemical profile, EHE shows characteristic myxochondroid background, much less pronounced cellular atypia and lower mitotic count than in EAS [15]. Approximately $30 \%$ of EHE show marked cytological atypia, foci of necrosis and higher mitotic activity which is associated with more aggressive behavior. The presence of solid growth should generally be regarded as a diagnostic clue in favor of EAS [15].

Melanoma with epithelioid morphology bears close resemblance to EAS and may be $\mathrm{CD} 34$-positive in about $1 / 3$ of cases [16]. However, melanoma does not express the other vascular markers like CD31 and factor VIII. In addition it shows expression of melanocytic antigens, like HMB-45 and melan A [16].

Anaplastic large cell lymphoma, regardless of the anaplastic lymphoma kinase (ALK) status, can show striking epithelioid morphology and cytokeratin expression. The clue in the diagnosis lies in the presence of horseshoe nuclei in the tumor cells as well as in positive reaction with lymphoid markers [17].

Epithelioid sarcoma (ES) shows variable histology, but common findings include epithelioid appearance of the neoplastic cells. Especially challenging in the differential diagnosis with epithelioid angiosarco$\mathrm{ma}$ is the so-called angiomatoid variant of ES which is formed by cystic, blood filled spaces bordered with epithelioid and spindle cells [15]. However, the cellular component in the classical (distal) form of epithelioid sarcoma is bland, resembling granulomatous reaction, thus its true biological potential may be overlooked. Additionally, contrary to the EAS, it shows constant and strong cytokeratin positivity. It is CD34 positive in around $50 \%$ of cases, but other vascular markers, like CD31 and factor VIII are missing [15].

\section{Conclusions}

Bone marrow metastases of angiosarcoma are extremely uncommon, but if they occur, they appear very early in the evolution of the disease. In such cases, bone marrow dissemination may become the main clinical symptom and usually this correlates with an unfavorable outcome in patients with this tumor.
This study was supported by grant ST-95 from the Medical University of Gdansk.

\section{References}

1. Weiss SH, Goldblum JR. Soft tissue tumors. Mosby Inc., Philadelphia 2008.

2. Deyrup AT, McKenney JK, Tighiouart M, et al. Sporadic cutaneous angiosarcomas: a proposal for risk stratification based on 69 cases. Am J Surg Pathol 2008; 32: 72-77.

3. Miettinen M, Fetsch JF. Distribution of keratins in normal endothelial cells and a spectrum of vascular tumors: implications in tumor diagnosis. Hum Pathol 2000; 31: 1062-1067.

4. Fayette J, Martin E, Piperno-Neumann S, et al. Angiosarcomas, a heterogeneous group of sarcomas with specific behavior depending on primary site: a retrospective study of 161 cases. Ann Oncol 2007; 18: 2030-2036.

5. Falk S, Krishnan J, Meis JM. Primary angiosarcoma of the spleen. A clinicopathologic study of 40 cases. Am J Surg Pathol 1993; 17: 959-970.

6. Geffen DB, Zirkin HJ, Mermershtain W, et al. Metastatic angiosarcoma of the spleen after accidental radiation exposure: a case report. Am J Clin Oncol 1998; 21: 167-170.

7. Wong KF, So CC, Wong N, et al. Sinonasal angiosarcoma with marrow involvement at presentation mimicking malignant lymphoma: cytogenetic analysis using multiple techniques. Cancer Genet Cytogenet 2001; 129: 64-68.

8. Vaiphei K, Singh V, Varma S. Splenic angiosarcoma presenting with jaundice, ascites and bone marrow fibrosis. Sarcoma 2003; 7 : 183-184.

9. Wang C, Rabah R, Blackstein M, et al. Bone marrow metastasis of angiosarcoma. Pathol Res Pract 2004; 200: 551-555.

10. Smith RA, Dzugan SA, Rafique S, et al. Angiosarcoma replacing bone marrow - a case report. J Miss State Med Assoc 2005; 46: 35-36.

11. Yilmazlar T, Kirdak T, Adim S, et al. A case of hemangiosarcoma in thyroid with severe anemia due to bone marrow metastasis. Endocr J 2005; 52: 57-59.

12. Noack F, Balleisen L, Valent P, et al. Angiosarcoma of bone marrow with unusual expression of chymase: diagnosis in a trephine biopsy specimen. J Clin Pathol 2007; 60: 1183.

13. Poblet E, Gonzalez-Palacios F, Jimenez FJ. Different immunoreactivity of endothelial markers in well and poorly differentiated areas of angiosarcomas. Virchows Arch 1996; 428 : 217-221.

14. Klijanienko J, Caillaud JM, Lagacé R, et al. Cytohistologic correlations in angiosarcoma including classic and epithelioid variants: Institut Curie's experience. Diagn Cytopathol 2003; 29: $140-145$

15. Dei Tos AP, Wagner AJ, Modena P, et al. Epithelioid soft tissue tumors. Semin Oncol 2009; 36: 347-357.

16. Leboit PE, Burg G, weedon D Pathology and genetics of tumors of the skin,

17. Swerdlow SH, Campo E, Harris NL. WHO Classification of Tumours of Haematopoietic and Lymphoid Tissues, IARC 2008.

\section{Address for correspondence}

Piotr Czapiewski

Department of Pathology

Medical University of Gdansk,

Dębinki 7

80-211 Gdansk, Poland

e-mail: czapiewskipiotr@gumed.edu.pl 